\title{
Correlation between Logical Thinking and Understanding of Science Concept
}

\author{
Fanny Sumirat \\ Universitas Islam " 45 ” Bekasi \\ Bekasi, Indonesa \\ harmonyzanki@gmail.com
}

\begin{abstract}
The cognitive development of students of elementary teacher education consists of their acquisition of knowledge and formation. Meaningful science encompasses scientific concept and cognitive skills. Having logical thinking abilities can be helpful for understanding the concept in science. Based on data of formative test, most studentst got bad examination results in the last semester. Some students think that learning science is very difficult. This study aims at describing a correlation between the logical thinking abilities and understanding of concept in science for the students of elementary teacher education. The 30 students chosen randomly are observed during the learning process in science. The result shows that there is a significant correlation of logical thinking and understanding of concept in science. A contribution logical thinking to understanding of concept in science is only $18.9 \%$; this is a low contribution. According to the scores on Test of Logical Thinking (TOLT), there are only $23.3 \%$ of the students who have reached the concrete stage; $53.3 \%$ of the students who have reached the transitional stage; and $23.3 \%$ of the students who have reached the formal stage. The other factor can influence to maintain their understanding and reasoning about the specific concept in science.
\end{abstract}

Keywords-Logical Thinking, Science Concept, Student Of Elementary Teacher Education

\section{INTRODUCTION}

The importance of learning in science for the students of elementary teacher education is to understand about concept and their thinking, that a science processes skill and develops a positive attitude. However, science perspective as one of subject matter is required in the education. In fact, our education is lack of giving the students changes to develop their holistic, creative or logical thinking and it does not make an attempt for mastery learning in the individual. Learning science does not only transfer knowledge from teacher to student, but also it is about knowledge construction through student thinking activity involving the processes and activities of scientific work. Commonly science in schools of Indonesia is more theoretic than inquiry, so the students are unable to solve the problems in daily life [1]. This condition takes the students to the university. Cognitive development of the student of elementary teacher education consists of their acquisition and formation of knowledge. Explanation on how human being to create knowledge has been influenced by four factors; there are language skill, logical thinking ability, experience, and interest [2]. Another has considered at that time we analyze data or process information to find the truth, surely we require of thinking skill.

Thinking process like capturing a reality, formulating into a sense, two or more understandings can be arranged into a decision. Finally the decision is assembled into a conclusion. The assertion of decision is expected to be a truth. The object observed requires a sensory experience directly in the surrounding environment and the activity of thinking is to generate ideas. Concept is one from of the ideas. Concept is an abstract and general representation of something. In science, concept is a basis for higher mental processes to formulate principles and generalizations [3]. The concept is a description of the characteristics of an object that may distinguish from the other object [4]. In accordance with Berg, concept is an abstraction of characteristics about something that facilitates communication among humans and allow humans to think [5]. It can be concluded that concept is an idea to describe certain characteristics of an activity that has meaning in order to facilitate communication. Usually learning concept in science becomes a serious problem, because every student has a different stimulus. Understanding concept must be appropriate to the rules based on which the concept is obtained

Piaget's theory on cognitive development involves a proper equilibrium between assimilation and accommodation [4]. That means, for this equilibrating process the students are active simultaneously to assimilate a piece of the environment and accommodate mental structures to understand better or adapt to the piece of the reality. Mental structures and schemas develop continuously. Furthermore, since the students have entered the school age, the cognitive development has evolved. Piaget divides the logical thinking stages into sensory-motor (ages 0-2 years), preoperational (age 2-7 years), concrete operational (age 7-11 years), and formal operational (age 11-16 years).

Based on data of formative test, most students got bad examination results in the last semester. Some students think that learning science is very difficult. However, the students comes into our classes with a range, prior ideas, or conceptions on the physical world. They are not 'empty vessels' [6]. The process to understand the concept enables every student to have different conceptions from the others based on their experiences of discovery on learning in science. Along with their age, learning in science encourages curiosity to investigate, predict, control variables, interpret data, 
formulate hypotheses, and communicate. Scientific knowledge takes the form of system of concept and theories [7].

Conceptual understanding involving the logical thinking helps the students to identify and correct their misconception. Meaningful science encompasses the scientific concept and cognitive skill. Having a logical thinking abilities can helpful to understand the concept in science. With logical thinking the students solve the problem by conducting the various mental practices, or reach principals or rules by executing some abstraction and generalization [8]. In accordance with Hackling, to be successful in science and in understanding the concepts of science are directly associated with formal reasoning skills [9].

\section{METHOD}

In this study, the researcher analyzes the data quantitatively. The samples of this study are 30 students chosen ramdomly; they were observed during their learning in science. Data were collected at two different ways. The students' logical thinking ability is measured by the Test of Logical Thinking (TOLT). This test was developed by [10] according to Piaget's cognitive developmental phase. TOLT consists of 10 items designed with multiple-choice format to measure variables of controlling, proportion, probability, correlation, and combination with reasoning. The students took the TOLT translated into Bahasa Indonesia. Classification of test scores is as follows: 0-1 is concrete, 2-3 are transitional, 4-7 are formal, and 8-10 are highly formal [11]. Assessment for understanding the concept of science was developed with the concept of science selected according to Bloom's Taxonomy. Students take the test using a paper-andpencil essay test format. This test consists of 75 questions.

\section{RESULTS AND DISCUSSION}

The result based on descriptive statistics (Table 1) indicates that the logical thinking student of elementary teacher education to have influence to understanding of concept in science.

TABLE I. MODEL SUMMARY

\begin{tabular}{|c|c|c|}
\hline & & Model \\
\hline & & 1 \\
\hline $\mathrm{R}$ & &, 435 \\
\hline $\mathrm{R} \mathrm{Sq}$ & & ,189 \\
\hline Adju & ed R Square &, 160 \\
\hline Std. & ror of the Estimate & 13,953 \\
\hline $\begin{array}{l}\text { Change } \\
\text { Statistics }\end{array}$ & $\begin{array}{l}\text { R Square Change } \\
\text { F Change } \\
\text { df1 } \\
\text { df2 } \\
\text { Sig. F Change }\end{array}$ & $\begin{array}{l}, 189 \\
6,517 \\
1 \\
28 \\
, 016\end{array}$ \\
\hline
\end{tabular}

According to table of Model Summary, the correlation between logical thinking and understanding of concept in science was low, namely: $\left(r_{x y}\right)=0.435$ and $F_{\text {change }}=$
6.517 with $\mathrm{p}$-value $=0.016<0$, 05. Whereas, the determination coefficients from table is R Square $=0.189$, the result indicated that contribution of logical thinking is only $18.9 \%$ to the understanding of concept in science. Most students used their thinking discrepancy between fact and concept. In fact, each student of elementary teacher education have conceptions different from the scientists' conceptions. Commonly these are called misconceptions [12], [13], [14]. These conceptions are similar in age, gender, abilities and culture [3]. Piaget has shown that some children begin to reflect an ability to engage in formal, abstract thought. As we have known that the cognitive development has a permanent and hierarchy stage, maturity, experience and social transmission. Naturally, in accordance with [15] intellectual development stage is hierarchy. The structure that seems in each stage is integration from the previous one, and consists of initial awareness and mastery periods. Transition of both periods continuously happen. Each of people follows the same sequence. That means, each of them has the same intellectual development since their infancy to adolescence.

However, most students of school elementary teacher education at Unisma Bekasi have a low understanding on science concept. Therefore, the students are not accustomed to using their thinking. That is the other factor than can influence to maintain their understanding and reasoning about the specific concept in science. Hence, planning and implementing a science program also requires a thorough understanding on students' characteristics. But, but in this study the consideration is in relation the curriculum, teaching effort and text book that can influence how the students contract their knowledge. In accordance with [5] that the nature and structure of science have often been presented as a set of fact, concept, and principles "given" to us by someone else. The matter that must be considered at this point is knowledge on what the students think about, because misconceptions on the part of the teacher can result a negative effect in the students' prior knowledge and deficiencies of understanding [16]. For example, a large proportion of many textbooks on science often present concept of science requiring a type of abstract thinking in the elementary grade, which is not provided for the students. Moreover, this problem ensures as a practical application for understanding functional characteristics on abstract and concrete thought. The development of an operational understanding of concept of classification, serration, number, space, time, weight, and other that have been considered is said to be necessary prerequisites to the later abstract thinking [5].

The abilities of the students' logical thinking can provide information about the cognitive level (Table 2). In accordance with Demirel, logical thinking includes effective use of numbers, finding scientific solutions to problems, realizing differences among concepts, classification, making generalization and calculations, and providing hypotheses [9]. 
TABLE II. FREQUENCY DISTRIBUTIONS OF SCORES FROM TOLT

\begin{tabular}{|c|c|c|c|}
\hline Interval Score & $\mathbf{f}$ & $\%$ & $\begin{array}{c}\text { Cognitive } \\
\text { Level }\end{array}$ \\
\hline $0-1$ & 7 & 23.3 & Concrete \\
\hline $2-3$ & 16 & 53.3 & Transitional \\
\hline $4-7$ & 7 & 23.3 & Formal \\
\hline $8-10$ & 0 & 0 & Rigorous formal \\
\hline Total & 30 & 100.00 & \\
\hline
\end{tabular}

Description on the students' logical thinking abilities of school elementary teacher education at Unisma Bekasi is almost in a transitional level. The results of Test of Logical Thinking (TOLT) are only $23.3 \%$ of the students reaching the concrete stage; $53.3 \%$ of them reaching the transitional stage; and $23.3 \%$ of them reaching the formal stage. That means that each of the students have different cognitive levels. Reference [5] cognitive development is a continuous process and shows a remarkably similar sequence among individual. The concrete students can also be identified that they are probably rather difficult to develop their thinking. In accordance with [17] concrete students can be instructed with instructional materials that provide first-hand experiences and concrete problems. To be able to promote meaningful learning, teacher should help students to construct abstract key concepts, to realize the interrelationships among the concepts, transfer and integrate what they learn in one course to another and to their daily lives. The formal students should be able to perform: hypothetical-deductive reasoning, probability, combination, identifying and controlling of variables, proportions and correlations, eliminating experimental contradiction, propositional logics [5]. And, the students of school elementary teacher education in concrete and transitional levels should be able reach the logical or abstract thought due to their thought development potency.

There are many ways to provide a rich learning environment facilitating the students to increase their knowledge; these are inquiry methods with constructivist approach [18], PBL approach [10] and conceptual change [19], [20], [21], [22].

\section{CONCLUSION}

Science should be facilitating the students to understand of science concept and their thinking. The students' conceptions from useful prior knowledge can build on [6 ]with logical thinking abilities that should be given new emphasis in the teaching and learning of science [23]. Thus, this is an attempt of educators to ensure of the students' optimum development toward logical or formal operations.

\section{REFERENCES}

[1] H. Suderajat, Kurikulum Berbasis KOmpetensi, Bandung: Cekas Grafika, 2004.

[2] L. Sutrisno, et.al. Pengembangan Pembelajaran IPA SD, Jakarta: Direktorat Jendral Pendidikan Tinggi Departemen Pendidikan Nasional, 2007

[3] R. Dahar, Teori-Teori Belajar dan Pembelajaran, Bandung: Erlangga,
1989.

[4] R. Good, How Children Learn Science, New York: MacMilan Publishing Co. Inc., 1977.

[5] A. Wibowo, "Karakteristik Sains," [Online]. Available: http://blog.uinmalang.ac.id.

[6] R. Titler, "Teaching for Understanding in Science: Student Conception Research and Changing View of Learning," Australian Science Teacher Journal, vol. 48, no. 3, pp. 14-21, 2002.

[7] Sizmur and A., "Introducing Scientific COncept to Children. National Foundation for Educational Research," [Online]. Available: http://www.nfer.ac.uk/publication.

[8] Bakir and B. , "Logical Thinking and Cognitive Development Level of Pre Service Science Teachers," Journal of Educational Sciences Research International, E-Journal, vol. 5, no. 1, 2015.

[9] S. Yaman, "Effectiveness on Development of Logical Thinking Skill of Problem Based Learning Skill in Sciencce Teaching," Journal of Turkish Science Education, vol. 2, no. 1, 2005.

[10] K. G. Tobin and W. Capie, "The Development and Validation of a Group Test of Logical Thinking," Educational and Psychological Measurement, vol. 41, pp. 413-423, 1981.

[11] N. C. Valanides, "Formal Reasoning and Science Teaching," 1996. [Online]. Available: http://www.oninelibrary.wiley.com.

[12] W. I. Sadia, Efektifitas Strategi Konflik Kognitif dalam Mengubah Miskonsepsi Siswa, Bali: STKIP Singaraja, 1997.

[13] Mujadi, "Pengaruh Pengalaman Anak dalam Terjadinya Miskonsepsi Fisika," 2002. [Online]. Available: http://lppm.ut.ac.id.

[14] A. Supriatna, "Strategi Anomali Data untuk Mengubah Miskonsepsi dan Meningatkan Pemahaman Siswa SD terhadap Konsep Cahaya," Tesis UPI, Unpublished, Bandung, 2009.

[15] B. H. Shulman, "Cognitive Therapy and the Individual Psychology of Alfred Adler," in Cognition and Psychoterapy, New York, Plenum, 1985, pp. 243-258.

[16] J. Hope and M. Townsend, "Student Teachers' Understanding of Science Concepts," in Research in Science Education, 1983, pp. 177183.

[17] Yenilmez, at. al. "Investigating Student's Logical Thinking AbilitiesL The Effect of Gender and Grade Level.," Hacettepe Üniversitesi Egitim Fakültesi Dergisi, vol. 28, p. 219, 2005.

[18] Awan, et. al. "Students' Misconception in Learning Basic Concept," International Journal of Applied Science and Technology, vol. 1, no. 4, 2011.

[19] G. J. Posner, K. Strike, P. Hewson and W. Gertzog, "Accomodation of Scientific Conception: Toward a Theory of Conceptual Change," 1982. [Online]. Available: http://www.onlinelibrary.wiley.com/doi/10.1002.

[20] A. Widodo and R. Duit, "Conceptual Change View and The Reality of Classroom Practise," 2002. [Online]. Available: http://file.upi.edu.

[21] M. Lee, "Is Using Discrepant Even and Effective Teaching Strategy to Promote Conceptual Change?," 2007. [Online]. Available: http://ww.csun.edu.

[22] Treagust and D. , "Multiple Perspectives of Conceptual Change in Schience and Challenge Ahead," Journal of Science and Mathematic Education in Southeast Asia, vol. 32, no. 2, pp. 89-104, 2009.

[23] L. Fah, "Logical Thinking Abilities among From 4 Students in the Interior Division of Sabah, Malaysia," Journal of Science and Mathematics Education in Southeast Asia, vol. 32, no. 2, pp. 161-187, 2009. 